\title{
Cortisol and migraine: A systematic literature review
}

\author{
Kortizol ve migren: Bir sistematik literatür derlemesi
}

\author{
Giuseppe LIPPI,' Camilla MATTIUZZI²
}

\begin{abstract}
Summary
Migraine is a highly prevalent and disabling disorder. Because stress appears to be a prominent trigger of this condition and cortisol is a well-established stress hormone, we performed a search on Medline, Scopus, and Web of Science to identify clinical studies that assessed cortisol levels in migraineurs. Four cross-section studies, one observational study, and three both cross-sectional and observational studies were finally included in our analysis. The heterogeneity was modest for the sample size (49.8\%) but was remarkably high for a sample matrix (66.0\%), thus precluding the possibility to meta-analyze the data. In six of the seven cross-sectional studies, cortisol levels did not differ between the cases and controls. With regard to the four observational trials, both nitroglycerine and human corticotropin-releasing hormone but not $\mathrm{m}$-chlorophenylpiperazine were effective in generating a more prominent cortisol release in migraineurs than in controls. In a fourth observation trial, salivary cortisol did not differ during the migraine attack and during the migraine free-period. In conclusion, even if altered corticotrope responsiveness exists in migraineurs, it appears to be irrelevant in the pathogenesis of migraine.
\end{abstract}

Keywords: Cortisol; headache; migraine; stress.

\begin{abstract}
Özet
Migren çok yaygın bir maluliyettir. Bu durumun başlıca tetikleyicisinin stres olduğu göründüğü ve kortizolde iyice bilinen bir stres hormonu olduğu için migren hastalarında kortizol düzeylerini değerlendiren klinik çalışmaları belirlemek için Medline, Scopus ve Web of Science tarama motorlarında araştırma yürüttük. Dört kesitsel, bir gözlemsel ve üç hem kesitsel hem de gözlemsel araştırma incelememize dahil edilmiştir. Örneklem büyüklüğüne göre heterojenlik orta derecede (\%49.8), ancak örnek matrisine göre hatırı sayılır derecede yüksek (\%66.0) olduğundan verilerin metaanalizini gerçekleştirmeyi olanaksızlaştırmıştır. Yedi kesitsel çalışmanın altısında kortizol konsantrasyonu olgular ve kontroller arasında farklılık göstermemiştir. Dört gözlemsel çalışma açısından, klorofenilpiperazinin aksine hem nitrogliserin, hem de insan kortikotropin serbestleştirici hormon kontrollere göre migren hastalarında daha belirgin bir kortizol salımına yol açmakta etkili olmuştur. Bir dördüncü gözlemsel çalışmada migren atağı sırasında ve migrensiz dönemde tükrükteki kortizol farklı değildi. Sonuçta, migren hastalarında kortikotropa yanıt verme yetisi bozulmuş olabilmesine rağmen bu durumun migrenin patogeneziyle ilgisi olmadığı görünmektedir.
\end{abstract}

Anahtar sözcükler: Kortizol; baş ağrısı ; migren; stres.

Migraine is a highly prevalent and disabling disorder, with an estimated prevalence of nearly $15 \%$ in the general population and a disability weight of approximately $43.3 \%{ }^{[1]}$ Although the exact pathogenesis of migraine is still incompletely understood, several lines of evidence now attest that a reduction of cerebral blood flow should be regarded as the primary trigger, which is then followed by a reactive vasodilatation of cerebral blood vessels, protein extravasation and contextual hypersensitization of pain pathways. ${ }^{[2,3]}$ Regardless of the presence of an aura (i.e., visual and/or sensory and/or speech disturbances occurring before the headache pain), the role of biological, psychological and environmental factors on triggering or aggravating migraine attacks has been now clearly acknowledged. ${ }^{[4]}$ Among these, stress seems to play a very prominent role.

By means of a self-administered headache questionnaire, Bánk and Márton assessed the potential correlates of migraine, and found that stress was by far the leading precipitating factor of headache pain

'Laboratory of Clinical Chemistry and Hematology, Academic Hospital of Parma, Parma, Italy

${ }^{2}$ Service of Clinical Governance, General Hospital of Trento, Trento, Italy

Submitted: 14.03.2014 Accepted after revision: 23.06.2017 Available online date: 04.10.2017

Correspondence: Dr. Camilla Mattiuzzi. Azienda Provinciale per i Servizi Sanitari, Via Degasperi 7938123 Trento - Italy.

Tel: +0039-0521-703050 e-mail: camilla.mattiuzzi@apss.tn.it

(c) 2017 Turkish Society of Algology 
( $90 \%$ of cases), ahead of sleep deprivation ( $58 \%$ of cases) and alcohol (30\% of cases) ${ }^{[5]}$ Similar evidence was also more recently reported by Fukui et al., who interviewed 200 consecutive migraineurs about possible trigger factors for headache episodes, and reported that stress was the lading precipitating factor (70.0\%; $p<0.001)$, followed by fasting (63.5\%), sleep deprivation (61.5\%) and alcohol (34.0\%). ${ }^{[6]}$

Cortisol is a well established stress hormone, which is released in response to a kaleidoscope of stimuli (e.g., fear, emotions, pain) by the adrenal glands. The leading functions of this hormone include the regulation of glucose homeostasis, the suppression of immune system, along with the activation of a number of anti-stress and anti-inflammatory pathways. ${ }^{[7]}$ Due to the clear relationship existing between stress and migraine, it is hence highly attractive for both clinical and therapeutic perspective to elucidate whether triggering or worsening of headache attacks in migraineurs may be supported or mediated by cortisol.

\section{Search criteria}

We carried out an electronic searched on Medline, Scopus and Web of Science (i.e., the mostly accessed biomedical research platforms), ${ }^{[8]}$ using the keywords "migraine" and "cortisol", with no language restriction. We applied a date restriction (1994 to present) in agreement with the publication of the definitive criteria for classification of migraine release by the International Headache Society (HIS) ${ }^{[9]}$ The references of retrieved items were also carefully analyzed for identifying additional published studies. Only those articles using standardized criteria for diagnosing migraine (i.e., those of the IHS), and reporting original data about the association between cortisol values in biological fluids and migraine were finally included. Heterogeneity across studies was assessed by chi-square based statistics and I-square test, with thresholds of $25 \%, 50 \%$ and $75 \%$ designating low, moderate and high heterogeneity. The methodological quality of the included studies was also assessed by QUADAS (quality assessment for studies of diagnostic accuracy, an evidence-based quality assessment tool for use in systematic reviews of diagnostic accuracy studies; maximum score 14) by the two authors. Potential discrepancies were resolved by consensus.

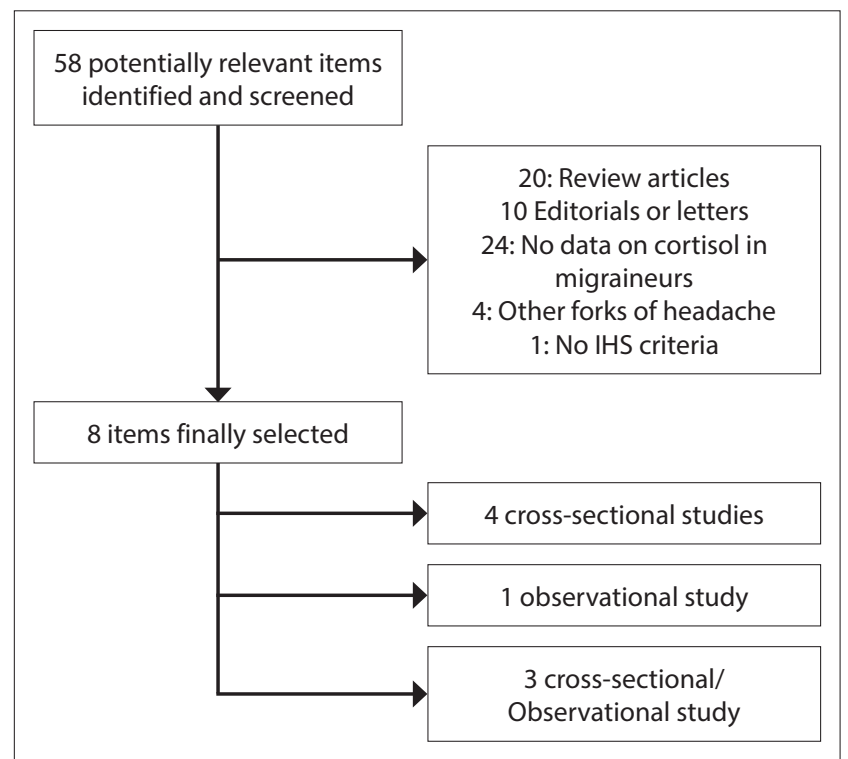

Figure 1. Flow diagram of study selection about the association between cortisol values and migraine.

The electronic search according to the predefined criteria generated 58 items after elimination of duplicates among the three biomedical platforms. The reference of the retrieved documents were also hand-searched for identifying additional pertinent studies. Careful reading of title, abstract and full text (when available) allowed to exclude 50 non pertinent items (Fig. 1). Therefore, 4 cross-section studies, 1 observational and 3 both cross-sectional and observational investigations were finally included in our analysis (Table 1). The quality of study design was acceptable, with a mean QUADAS score of $10 \pm 3$. The inter-study variability of the 7 cross-sectional trials about cortisol concentration in migraineurs and healthy controls was modest for the sample size (49.8\%; chi-squared, $13.9 ; D F, 7)$, but was found to be remarkably high for the sample matrix $(66.0 \%$; chisquared, $20.61 ; D F, 7)$, thus precluding the possibility to meta-analyze the data.

\section{Review of clinical trials}

Leone et al. measured morning serum cortisol levels in 12 migraineurs without aura (5 females and 7 males, mean age, $34 \pm 8$ years) and in 14 matched healthy controls ( 5 females, 9 males; mean age, 38 \pm 12 years). ${ }^{[10]}$ Baseline serum cortisol levels did not differ in the two groups (values not reported; $p=n s$ ). Both groups of patients were then challenged with two tests, one with $0.5 \mathrm{mg} / \mathrm{kg}$ oral m-chlorophenylpiperazine (mCPP) and the other with placebo, by means of a double-blind crossover format. The area 


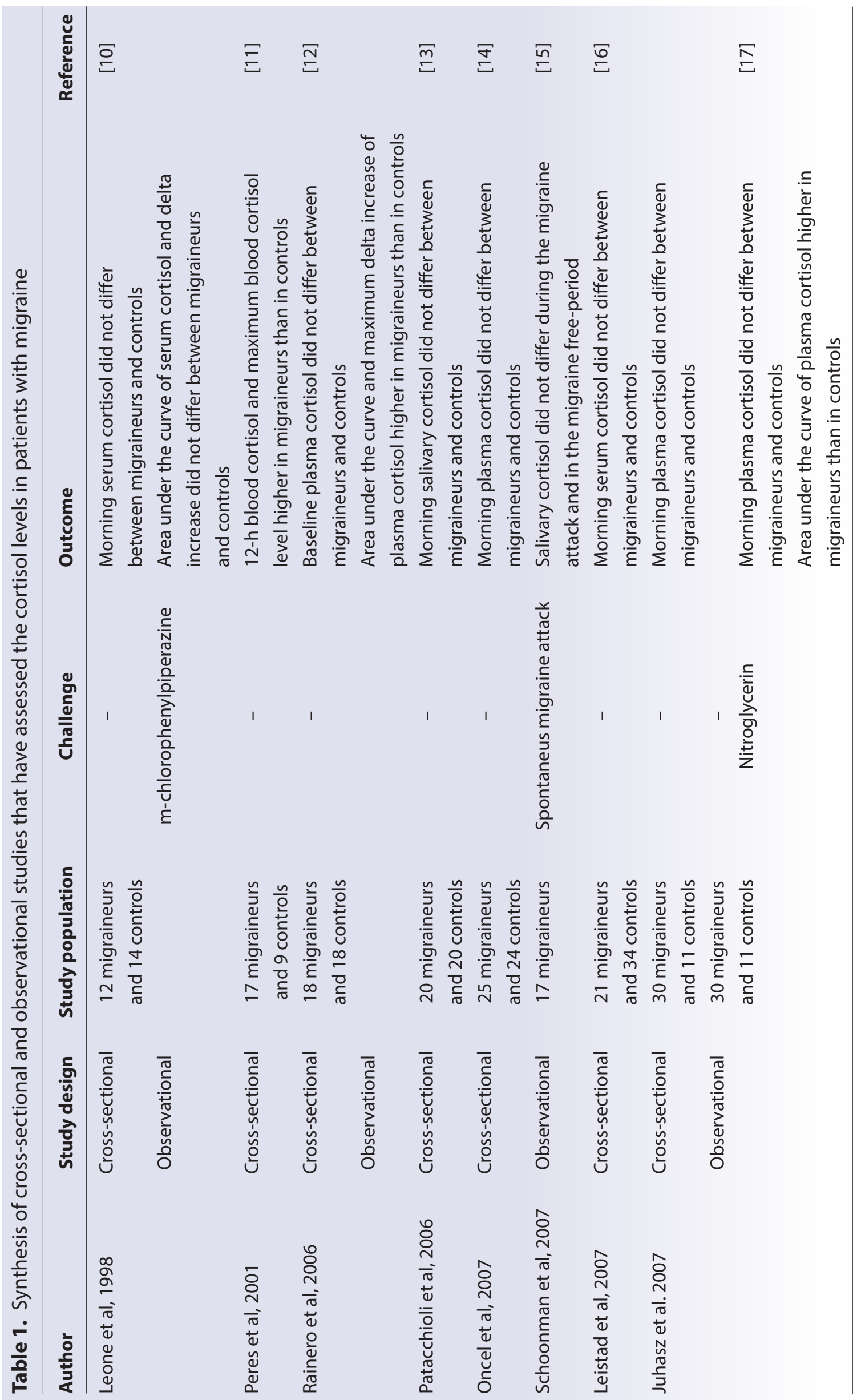


under the curve (AUC) of serum cortisol up to 3 hours after the challenge did not differ between cases and controls ( $294 \pm 211$ versus $444 \pm 175 \mu \mathrm{g} / \mathrm{dL}$ per hour; $p=n s)$. The maximum delta increase of cortisol values was also similar between cases and controls $(0.83 \pm 0.30$ versus $1.04 \pm 0.24 ; p=n s)$.

Peres et al. monitored cortisol in blood samples (sample matrix not clearly specified) taken every hour (from 7 p.m. to 7 a.m.) from 17 patients with chronic migraine ( 3 males and 14 females; mean age, $31 \pm 9$ years), and 9 age and sex matched healthy volunteers ( 2 males and 7 females; mean age, 29 \pm 6 years). ${ }^{[11]}$ Interestingly, the AUC of total cortisol concentration $(101.7 \pm 49.0$ versus $76.6 \pm 14.3 \mu \mathrm{g} . \mathrm{h} / \mathrm{dL}$; $\mathrm{p}<0.005)$ as well as the cortisol peak $(22.5 \pm 14.2$ versus $18.6 \pm 4.1 \mu \mathrm{g} / \mathrm{dL}$ ) were significantly higher in migraine patients than in controls.

Rainero et al. investigated 18 patients with migraine and medication-overuse headache ( 3 males and 15 females; mean age, $44 \pm 10$ years) and 18 healthy controls ( 3 males and 15 females; mean age, $40 \pm 8$ years). ${ }^{[12]}$ The basal concentration of plasma cortisol was not found to be significantly different between cases and controls (values not reported; $\mathrm{p}=\mathrm{ns}$ ). However, $15 \mathrm{~min}$ after administration of $100 \mu \mathrm{g}$ human corticotropin-releasing hormone ( $\mathrm{hCRH}$ ) in both groups, the maximum delta increase of serum cortisol was significantly higher in cases than in controls, with a total AUC of plasma cortisol secretion up to $90 \mathrm{~min}$ after hCRH administration that was found to be more than 2-fold higher in cases than in controls $(p=0.01)$.

Morning salivary cortisol was also assessed by Patacchioli et al. in 20 women with chronic migraine (mean age, 50 \pm 4 years) and 20 female controls subjects (mean age, $49 \pm 3$ years), ${ }^{[13]}$ and no significant differences were recorded between the control group $(46.9 \pm 4.2 \mathrm{pg} / \mathrm{mL})$ and the chronic migraine group $(47.7 \pm 5.0 \mathrm{pg} / \mathrm{mL})$.

Oncel et al. measured plasma cortisol levels between 8.30-9.30 a.m. in 25 migraine patients (4 males and 21 females; mean age, $33 \pm 8$ years) and 24 healthy controls ( 2 males and 21 females; mean age, $28 \pm 6$ years) ${ }_{,}^{[14]}$ but failed to find significant differences between cases and controls (15.1 \pm 5.8 versus $16.7 \pm 6.7$ $\mathrm{ng} / \mathrm{mL} ; \mathrm{p}=0.91$ ). No significant difference was also found in the cortisol values of migraine patients with or without aura.

In an observational study, Schoonman et al. assessed the potential temporal relationship existing between salivary cortisol and onset of a migraine attack in 17 migraine patients ( 4 males and 13 females; mean age, $41.8 \pm 9.9$ years). ${ }^{[15]}$ Interestingly, the concentration of salivary cortisol was found to be not significantly different during the migraine attack (15.8 \pm 6.7 $\mathrm{ng} / \mathrm{mL})$ and 4 days before the episode $(14.4 \pm 3.9 \mathrm{ng} /$ $\mathrm{mL} ; \mathrm{p}=\mathrm{ns})$.

Leistad et al. measured baseline serum cortisol in 21 migraine patients ( 2 males and 19 females; mean age, 41 years and range 21-60 years) and in 34 healthy controls ( 4 males and 30 females; mean age, 41 years and range 19-61 years), ${ }^{[16]}$ and failed to find any significant difference between cases and controls (values not reported; $p=n s$ ).

Juhasz et al. assessed plasma cortisol concentration in 30 unrelated migraine patients without aura (mean age, $44 \pm 1$ years) and 11 unrelated healthy controls (mean age, $42 \pm 3$ years), ${ }^{[17]}$ and found that the baseline plasma cortisol concentration was in the normal range $(466 \pm 17 \mathrm{nmol} / \mathrm{L})$ in the whole study population, with no significant differences between cases and controls (values not reported; $\mathrm{p}=\mathrm{ns}$ ). After sublingual application of $0.5 \mathrm{mg}$ nitroglycerin to the entire study population, a migraine attack fulfilling the ISH criteria developed in 0 control subjects (0\%) and 22 migraineurs (73\%; mean headache score: $3.7 \pm 0.5)$. A highly significant correlation was observed between variation of headache scores and plasma cortisol changes at the second hour of migraine attack $(r=0.61 ; p<0.001)$. Accordingly, the delta cortisol variation was more than 2 -fold higher in migraine patients than in controls $(p=0.001)$.

\section{Conclusions}

The identification of biological mediators that can trigger or worsen a migraine attack should be regarded as an attractive perspective for prevention or treatment of this highly prevalent and disabling condition worldwide. ${ }^{[18,19]}$ It is now well established that stress should be regarded as an important precipitating factor of migraine. Since cortisol is consistently produced and secreted by the adrenal grand in re- 
sponse to eustress and distress, more than 20 years ago it has been hypothesized that this hormone may be involved in the pathogenesis of migraine. ${ }^{[20]}$

Taken together, the results of our systematic literature review attest that the baseline cortisol values are unlikely to be higher in migraineurs than in controls. More specifically, in six out of the seven crosssectional studies included in our analysis the concentration of cortisol did not differ between cases and controls, regardless of the biological matrix used for hormone measurement (i.e., serum plasma or saliva) (Table 1). As regards the four observation trials, at variance with the MCPP challenge, both nitroglycerine and hCRH were effective to generate a cortisol release that was more accentuated in migraineurs than in controls (Table 1). Even more importantly, however, in the fourth observation trial it was reported that salivary cortisol did not differ during the migraine attack and in the migraine free-period. As such, even if a sort of altered corticotrope responsiveness may exist in migraineurs, this seems to be irrelevant in the pathogenesis of this condition.

\section{Conflict-of-interest issues regarding the authorship or article: None declared.}

\section{Peer-rewiew: Externally peer-reviewed.}

\section{References}

1. Steiner TJ, Stovner LJ, Birbeck GL. Migraine: the seventh disabler. Headache 2013;53(2):227-9.

2. Goadsby PJ. Cortical spreading depression-better understanding and more questions. Focus on "distinct vascular conduction with cortical spreading depression". J Neurophysiol 2007;97(6):3827.

3. Headache Classification Committee of the International Headache Society (IHS). The International Classification of Headache Disorders, 3rd edition (beta version). Cephalalgia 2013;33(9):629-808.

4. Hoffmann J, Recober A. Migraine and triggers: post hoc ergo propter hoc? Curr Pain Headache Rep 2013(10);17:370.

5. Bánk J, Márton S. Hungarian migraine epidemiology. Headache 2000;40(2):164-9.

6. Fukui PT, Gonçalves TR, Strabelli CG, Lucchino NM, Matos
FC, Santos JP, et al. Trigger factors in migraine patients. Arq Neuropsiquiatr 2008;66(3A):494-9.

7. Fukuda S, Morimoto K. Lifestyle, stress and cortisol response: Review II : Lifestyle. Environ Health Prev Med 2001;6(1):15-21.

8. Lippi G, Favalor EJ, Simundic AM. Biomedical research platforms and their influence on article submissions and journal rankings: an update. Biochem Med (Zagreb) 2012;22(1):7-14.

9. Olesen J, Lipton RB. Migraine classification and diagnosis. International Headache Society criteria. Neurology 1994;44(6 Suppl 4):S6-10.

10. Leone M, Attanasio A, Croci D, Ferraris A, D'Amico D, Grazzi $\mathrm{L}$, et al. 5-HT1A receptor hypersensitivity in migraine is suggested by the m-chlorophenylpiperazine test. Neuroreport 1998;9(11):2605-8.

11. Peres MF, Sanchez del Rio M, Seabra ML, Tufik S, Abucham J, Cipolla-Neto J, et al. Hypothalamic involvement in chronic migraine. J Neurol Neurosurg Psychiatry 2001;71(6):74751.

12. Rainero I, Ferrero $M$, Rubino $E$, Valfrè $W$, Pellegrino $M$, Arvat $E$, et al. Endocrine function is altered in chronic migraine patients with medication-overuse. Headache 2006;46(4):597-603.

13. Patacchioli FR, Monnazzi P, Simeoni S, De Filippis S, Salvatori E, Coloprisco G, et al. Salivary cortisol, dehydroepiandrosterone-sulphate (DHEA-S) and testosterone in women with chronic migraine. J Headache Pain 2006;7(2):90-4.

14. Oncel C, Oflazoğlu B, Forta H, Yücel N, Eren N. Plasma cortisol levels in migraineurs between attacks. Agri 2007;19(2):46-8.

15. Schoonman GG, Evers DJ, Ballieux BE, de Geus EJ, de Kloet $E R$, Terwindt GM, et al. Is stress a trigger factor for migraine? Psychoneuroendocrinology 2007;32(5):532-8.

16. Leistad RB, Stovner LJ, White LR, Nilsen KB, Westgaard RH, Sand T. Noradrenaline and cortisol changes in response to low-grade cognitive stress differ in migraine and tensiontype headache. J Headache Pain 2007;8(3):157-66.

17. Juhasz G, Zsombok T, Gonda X, Nagyne N, Modosne E, Bagdy $G$. Effects of autogenic training on nitroglycerininduced headaches. Headache 2007;47(3):371-83.

18. Benbir G, Karadeniz D, Göksan B. The characteristics and subtypes of headache in relation to age and gender in a rural community in Eastern Turkey. Agri 2012;24(4):145-52.

19. Lippi G, Mattiuzzi C, Meschi T, Cervellin G, Borghi L. Homocysteine and migraine. A narrative review. Clin Chim Acta 2014;433:5-11.

20. Galiano L, Montiel I, Falip R, Asensio M, Matías-Guiu J. Stress as a precipitating factor in migraine. Rev Neurol 1995;23(122):830-2. 